Pengaruh Model Pembelajaran.... (Kiki Amelia, Hetilaniar, Masnunah)

\title{
PENGARUH MODEL PEMBELAJARAN SINEKTIK TERHADAP KEMAMPUAN MENULIS PUISI SISWA SMP PATRA MANDIRI 2
}

\author{
Oleh: Kiki Amelia, Hetilaniar, Masnunah \\ Email : Kikiamelia01101997@gmail.com, Heti_ardesya@yahoo.com, \\ Masnunah42@gmail.com \\ (Universitas PGRI Palembang)
}

\begin{abstract}
Abstrak
Tujuan penelitian ini untuk mengetahui adanya pengaruh model pembelajaran sinektik terhadap kemampuan menulis puisi siswa kelas VIII SMP Patra Mandiri 2 Palembang. Metode penelitian yang digunakan yaitu metode True Eksperimental Design Tipe Posstest Only Control Design. Teknik analisis data yang digunakan adalah teknik tes dan dokumentasi. Hasil Penelitian terhadap kemampuan menulis puisi siswa kelas VIII SMP Patra mandiri 2 Palembang. Hasil nilai perhitungan data belajar siswa menggunakan uji-t (T Test dari Anova) yang terdapat pada sebuah program SPSS versi 19. Menunjukkan bahwa yang berarti jika nilai Sig > 0,05 maka distribusi data homogen, dan jika nilai Sig < 0,05 maka distribusi data tidak homogen. Hasil perhitungan nilai signifikan diatas nilai yang diperoleh ternyata uji-t 0,54 >0,05. Berarti nilai Sig $>$ 0,05 maka peneliti menyimpulkan bahwa "Ada Pengaruh Model Pembelajaran Sinektik Terhadap Kemampuan Menulis Puisi Siswa Kelas VIII SMP Patra mandiri 2 Palembang".
\end{abstract}

Kata Kunci : Model Pembelajaran Sinektik, Menulis Puisi

\section{THE INFLUENCE OF SYNECTIC LEARNING MODELS ON THE ABILITY OF WRITING POETS STUDENTS OF SMP PATRA MANDIRI 2}

\begin{abstract}
The purpose of this study was to determine the effect of synectic learning models on the ability to write poetry for eighth grade students of Patra Mandiri 2 Junior High School in Palembang. The research method used is the True Experimental Design Type Posstest Only Control Design. The data analysis technique used is the test and documentation technique. Research Results on the ability to write poetry for eighth grade students of Patra Mandiri 2 Junior High School in Palembang. The results of the calculation of student learning data using the t-test (T Test from Anova) contained in an SPSS version 19. It shows that which means that if the Sig value> 0.05 then the homogeneous data distribution, and if the Sig value <0.05 then data distribution is not homogeneous. The result of calculating the significant value above the value obtained turns out to be t-test 0.54>0.05. Meaning a Sig value> 0.05, the researcher concludes that "There is an Effect of a Synectic Learning Model on the Ability to Write Poetry in Class VIII Middle School Independent Patra 2 Palembang Students".
\end{abstract}


Wahana Didaktika Vol. 18 No.3 September 2020 : 329-337

Keywords: Synectic Learning Model. Writing Poetry

\section{A. PENDAHULUAN}

Keberhasilan pendidikan tidak terlepas dari beberapa faktor yang mendasarinya, antara lain, siswa, pendidik, lingkungan, alat, metode, media dan tujuan. Selain itu, keberhasilan siswa dalam belajar sangan tergantung pada pribadi siswa itu dalam menekuni semua mata pelajaran, lingkungan dan guru turut menentukan prestasi belajar siswa. Seorang siswa berusaha untuk memperoleh perubahan tingkah laku untuk mencapai tujuan belajar.

Pada setiap tingkat pendidikan, salah satu mata pelajaran penting yaitu mata pelajaran bahasa indonesia yang menjadi salah satu mata pelajaran yang wajib dimiliki oleh siswa indonesia. Karena pentingnya keterampilan menulis, pengembangan pembelajaran menulis perlu ditingkatkan dengan metode-metode yang dapat membangun siswa dalam mengembangkan keterampilan menulis. Dengan upaya tersebut, tujuan pembelajaran diharapkan tercapai, Pembelajaran bahasa indonesia sangat penting untuk kehidupan sehari-hari terutama dalam menulis. Selanjutnya penggunaan strategi atau metode yang tepat dapat memperbaiki dan meningkatkan keterampilan mahasiswa dalam menulis (Armariena, 2018, p. 54).

Menurut Marwanto (Tarigan, 2008) menjelaskan bahwa menulis adalah mengungkapkan ide atau gagasannya dalam bentuk karangan secara leluasa. Dalam hal ini, menulis itu membutuhkan skemeta yang luas sehingga penulis mampu menuangkan ide, gagasan, pendapatnya dengan mudah dan lancar. Selanjutnya Dalman (2016) menulis merupakan suatu keterampilan berbahasa yang dipergunakan untuk berkomunikasi secara tidak langsung, tidak secara tatap muka dengan orang lain, Menulis merupakan suatu kegiatan yang produktif dan eksperesif. Suparno dan Yunus dalam (Tarigan, 2008) Menulis merupakan suatu kegiatan penyampaian pesan komunikasi dengan mengunakan bahasa tulis sebagai alat atau medianya.

Dari pengertian menulis menurut para ahli di atas, maka dapat disimpulkan bahwa menulis merupakan kegiatan komunikasi atau penyampain pesan secara 
tidak langsung, berupa penyampaian pesan (komunikasi) dengan mengunakan bahasa tulis sebagai alat dan medianya yang mengungkapkan ide, dan gagasan, pendapatnya dengan mudah dan lancar. Oleh karena itu, diperlukan kreativitas siswa salah satunya dalam menulis puisi, siswa dapat berlatih menulis karangan baik itu fiksi maupun non fiksi. Berlatih menulis non fiksi dapat dilakukan oleh siswa dalam menulis puisi, Puisi adalah salah satu mata pelajaran yang diajarkan di sekolah. Materi yang diajarkan terkait dengan materi puisi, salah satunya adalah menulis puisi. Pembelajaran ini di sekolah diberikan pada siswa kelas VIII semeter II dengan kompetensi indahnya berpuisi (Kosasih, 2017).

Komaidi dan Waluyo dalam (Aminuddin, 2009) Puisi adalah salah satu genre atau jenis sastra, Sering kali istilah "puisi" disamakan dengan "sajak". Akan tetapi, sebenarnya tidak sama, puisi itu merupakan jenis sastra yang melingkupi sajak sedangkan sajak adalah bagian atau individu dari puisi yang mengungkapkan pikiran dan perasaan penyair secara imajinatif yang disusun dengan mengkonsentrasikan semua kekuatan bahasa deng melihat dari struktur fisik dan struktur batinnya.

Selanjutnya, Kosasih (2017) Puisi adalah teks atau karangan yang mengungkapkan pikiran dan perasaan dengan mengutamakan keindahan katakata. Puisi mengungkapkan berbagai hal. Kerinduan, kegelisahan, atau pengangungan kepada sang khalik yang kamu ungkapkan dalam bahasa yang indah. Namun, untuk menunjang kompetensi guru dalam meningkatkan hasil belajar kesusastraan yang disajikan dalam bentuk puisi pada siswanya, maka diperlukan suatu strategi yang tepat agar tercapai tujuan pembelajaran yang efektif. Strategi digunakan untuk mengontrol dan menginformasikan kepada kita tentang tindakan apa yang harus diambil (Hetilaniar \& Auliya, 2019, p. 160). Untuk mengukur kemampuan menulis puisi siswa maka diperlukan model pembelajaran yang tepat, yaitu model pembelajaran sinektik.

Gordon dalam kutipan Wijaya (2013:5) model pembelajaran yang dirancang untuk berfikir kritis dan kreatif. Oleh sebab itu dalam penelitian ini, Model pembelajaran sinektik yang diajarkan kepada siswa, karena hal ini bisa memecahkan masalah kesulitan pada siswa yang belum memahami dengan jelas 
terhadap kemampuan dalam menulis puisi. Melalui model pembelajaran yang tepat, mahasiswa diharapkan mampu menulis puisi sesuai dengan ejaan yang baik dan benar (Armariena \& Murniviyanti, 2017).

Berdasarkan observasi awal peneliti sebelum adanya wabah covid 19 terhadap siswa kelas VIII SMP Patra mandiri 2 Palembang. Observasi awal yang dilakukan peneliti bahwa pembelajaran dalam kemampuan menulis siswa masih rendah dilihat dari bentuk tulisan puisi antara lain dalam menuangkan ide gagasan atau perasaan yaitu (1) Siswa belum memahami tentang puisi (2) Siswa belum bisa merangkai kata-kata dalam puisi (3) Guru masih mengunakan model pembelajaran konvensial. Berdasarkan latar belakang, peneliti tertarik untuk meneliti dengan judul "Pengaruh Model Pembelajaran Sinektik Terhadap Kemampuan Menulis Puisi Siswa Kelas VIII SMP Patra Mandiri 2 Palembang.

Dengan adanya wabah covid 19 yang terjadi sejak bulan Febuari 2020 sangat mempengaruhi peneliti dalam melakukan penelitian mengenai "Pengaruh Model Pembelajaran Sinektik Terhadap Kemampuan Siswa Terhadap Kemampuan Menulis Puisi Siswa Kelas VIII SMP Patra Mandiri 2 Palembang” secara langsung sehingga membuat peneliti melakukan penelitian secara online yang membuat kesulitan peneliti untuk mendapatkan hasil yang objektif karena terkendala fasilitas dan tidak semua daerah memiliki kestabilan jaringan internet.

Selain itu, masalah lain yang perlu peneliti perhatikan adalah para siswa juga mengalami kesulitan untuk melakukan konsultasi dengan guru terutama untuk pelajaran yang di anggap membutuhkan penjelasan dan pemahaman yang mendalam. Sementara kelebihannya dalam melakukan penilitian online ini waktu menjadi lebih fleksibel dan adanya bahan pembelajaran yang terstuktur dan terjadwal dengan baik melalui internet serta dapat diakses kapanpun sehingga siswa dapat menjadi aktif dalam proses pembelajaran secara online.

\section{B. METODOLOGI PENELITIAN}

Penelitian ini merupakan penelitian kuantitatif dengan mengunakan metode penelitian eksperimen yang digunakan yaitu metode True Eksperimental Design Tipe Posttest Only Control Design. Populasi dalam penelitian ini adalah 
pada kelas VIII B kontrol dan pada kelas VIII A eksperimen SMP Patra mandiri 2 Palembang yang keseluruhannya berjumlah 42 siswa masing-masing satu kelas terdiri dari kelas VIIIA terdiri 24 siswa dan kelas VIIIB terdiri 21 siswa yang terdaftar pada tahun 2020.

Penelitian ini dilaksanakan pada semester genap tahun pembelajaran 2020/2021 di SMP Patra Mandiri 2 Palembang dengan populasi seluruh siswa kelas VIII yang berjumlah 44 siswa Hasil kemampuan menulis puisi siswa kelas VIII menggunakan alat pengumpulan data dan instrumen tes. Peneliti menggunakan seluruh siswa pada kelas VIIIA sebagai kelas eksperimen dan pada kelas VIIIB sebagai kelas kontrol. Peneliti melakukan posstest sebagai tes akhir dengan tes dalam menulis puisi sebagai alat untuk mengukur dalam mengetahui kemampuan akhir siswa setelah diberi pembelajaran daring sebanyak empat kali dengan menggunakan model pembelajaran sinektik. Data dianalisis dengan menggunakan uji normalitas, uji homogenitas, uji hipotesis dari 2 kelas menggunakan SPSS versi 19.

Pada bab ini akan diuraikan bagian deskripsi pelaksanaan data penelitian tentang hasil tes dan dokumentasi yang dilakukan di SMP Patra Mandiri 2 Palembang. Berdasarkan uraian data hasil tes kemampuan menulis puisi siswa kelas VIII yang brjumlah 42 peserta didik sampel dari dua kelas yang berbeda yaitu kelas eksperimen berjumlah 21 peserta didik dan kelas eksperimen 21 peserta didik, dan penelitian dilaksanakan pada tanggal 12 Mei 2020.

\section{HASIL PENELITIAN DAN PEMBAHASAN}

\section{Hasil Uji Normalitas Data Sampel Kelas Eksperimen}

Uji normalitas dilakukan pada data skor tes akhir posttest di kelas eksperimen setelah mengalami proses pembelajaran dengan mengunakan salah satu model pembelajaran sinektik terhadap kemampuan menulis dan diolah dengan menggunakan teknik Komogrov-Sminorniv dalam suatu program SPSS versi 19. Dengan hasil pengolahan data yakni untuk lebih jelas dapat di lihat di bawah ini sebagai berikut. 
Tabel 1 Deskripsi Hasil Postest Kemampuan Menulis Puisi Kelas Eksperimen

\begin{tabular}{|l|r|r|r|r|c|}
\hline $\begin{array}{l}\text { Nilai Post-Test } \\
\text { Eksperimen }\end{array}$ & $\mathrm{N}$ & Minimum & Maximum & Mean & $\begin{array}{c}\text { Std. } \\
\text { Deviation }\end{array}$ \\
\cline { 2 - 6 } & 21 & 72 & 90 & 81.86 & 5.247 \\
\hline
\end{tabular}

(Sumber: data nilai kemampuan menulis puisi)

Pada tabel di atas. Diketahui bahwa jumlah sampel pada kelas eksperimen sebanyak dua puluh satu orang, nilai terendah tujuh puluh dua, nilai tertinggi sembilan puluh, rata-rata 81,86 dan nilai keseluruhan lima ribu dua ratus empat puluh tujuh.

Untuk terlihat lebih jelas distribusi kemampuan menulis puisi pada siswa kelas eksperimen ditunjukan pada normal Q-Q plot of hasil menulis puisi.

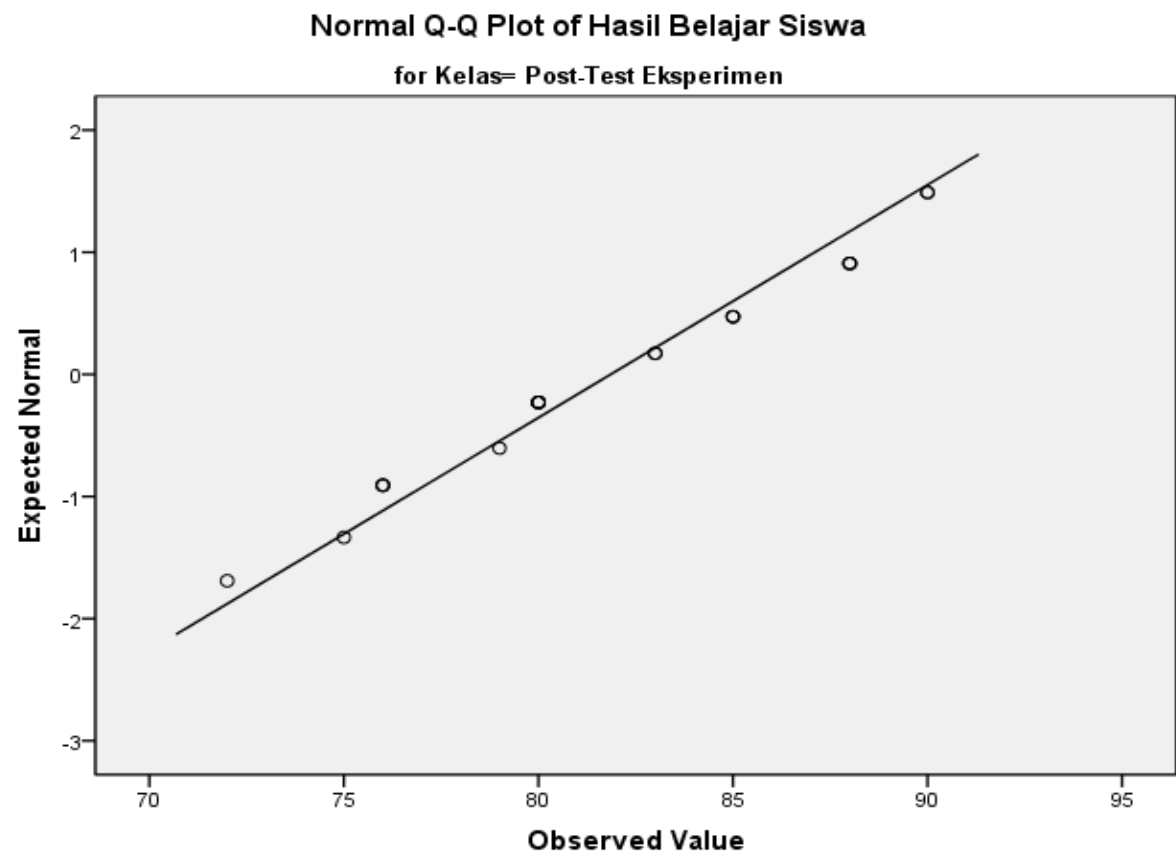

\section{Gambar. 1 Uj normalitas Kemampuan Menulis Puisi Siswa Kelompok eksperimen}

Untuk lebih jelas dari gambar Q-Q Plat of hasil menulis puisi siswa di atas, terlihat jarak nilai pengamatan dengan nilai harapan ialah minimum. Hal ini terlihat dari banyaknya titik sampel yang telah berada di sekitar garis normal.

\section{Hasil Uji Normalitas Sampel Data Kelas Kontrol}


Untuk mengetahui adanya hasil awal maka dapat dilakukan dengan menggunakan uji normalitas yaitu dilakukan pada hasil akhir kemampuan menulis puisi setelah mengalami pembelajaran dengan tahap model pembelajaran konvensional dan diolah dengan menggunakan teknik Kolmogorov-Smirnov yang telah terdapat pada program SPSS versi 19.

Pada tabel deskripsi hasil nilai pengolahan data dalam kemampuan menulis puisi pada kelompok kontrol yakni.

Tabel 2 Deskripsi Hasil Posstest Kemampuan Menulis Puisi Kelas Kontrol

\begin{tabular}{|l|r|r|r|r|r|}
\hline $\begin{array}{l}\text { Nilai Post-Test } \\
\text { Kontrol }\end{array}$ & N & Minimum & Maximum & Mean & $\begin{array}{c}\text { Std. } \\
\text { Deviation }\end{array}$ \\
\cline { 2 - 6 } & 21 & 70 & 82 & 75,43 & 3.749 \\
\hline
\end{tabular}

(Sumber: data nilai kemampuan menulis puisi)

Pada tabel di atas. Diketahui bahwa jumlah sampel untuk kelas eksperimen sebanyak 21 orang, nilai terendah tujuh puluh, nilai tertinggi delapan puluh dua, rata-rata 75,43 dan nilai keseluruhan tiga ribu tujuh ratus empat puluh sembilan.

Untuk melihat yang jelas distribusi kemampuan menulis siswa kelas kontrol ditunjukkan pada normal Q-Q plot of hasil kemampuan menulis puisi.

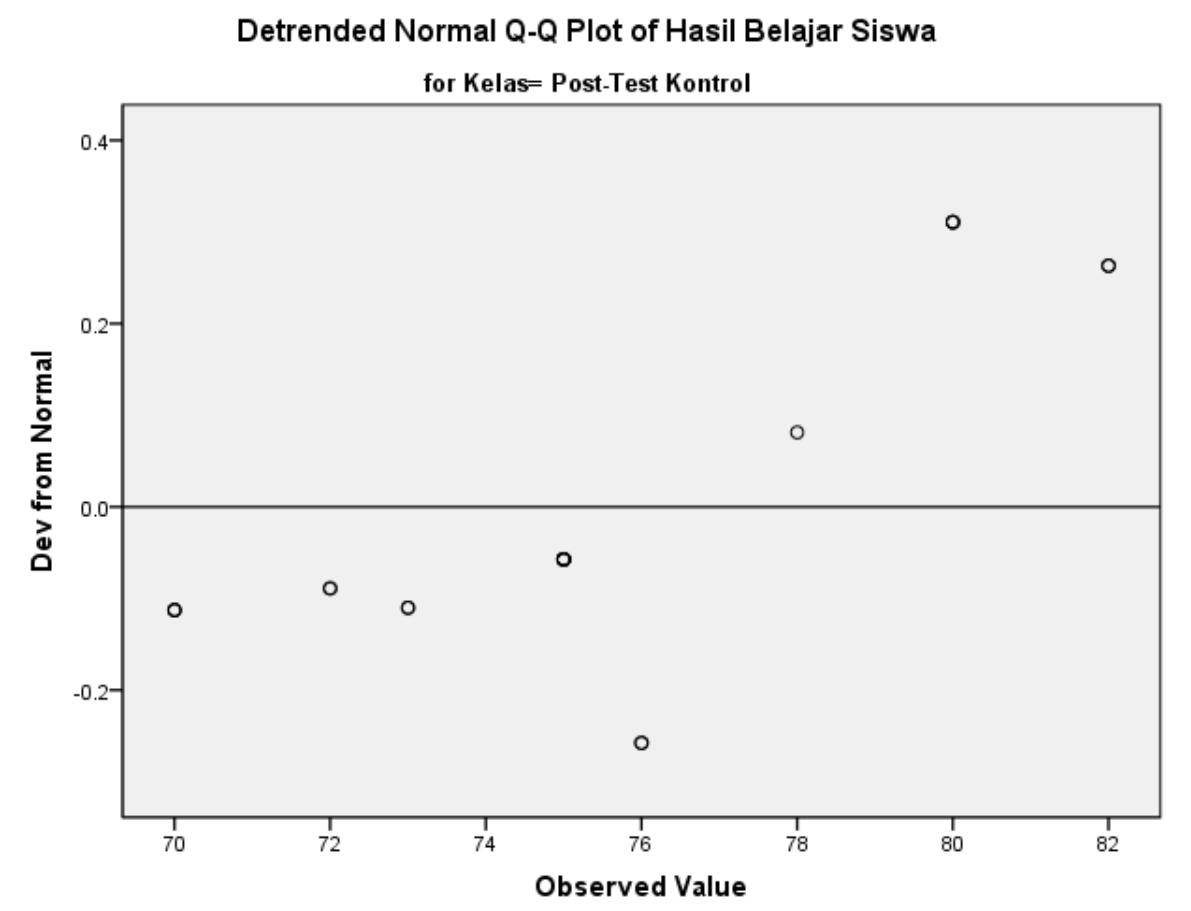

Gambar 2. Uji normalitas Kemampuan Menulis Puisi Siswa Kelompok Kontrol 
Gambar Q-Q Plot Kemampuan Menulis Puisi Siswa diatas terlihat bahwa jarak nilai pengamatan dengan nilai harapan adalah minimum. Hal ini terlihat banyaknya titik-titik sampel yang berada di sekitar garis normal. Jadi, Sampel berasal dari populasi yang berdistribusi tidak normal.

\section{Hasil Uji Homogenitas}

Uji homogenitas ini dilakukan untuk menguji apakah sampel yang akan diambil dan mempunyai variasi yang sama (Homogen). Uji homogenitas dalam penelitian ini dilakukan terhadap hasil nilai kemampuan menulis puisi siswa dari kelas eksperimen dan siswa kelas kontrol. Pengujian ini digunakan untuk meyakinkan bahwa kelompok data memang berasal dari populasi yang memiliki varians yang sama (homogen) yaitu siswa kelas VIII SMP Patra Mandiri 2 Palembang. Dasar pengambilan keputusan untuk homogenitas ini jika nilai Sig > 0,05 maka distribusi data homogen dan jika nilai Sig $<0,05$ maka distribusi data tidak homogen. Berikut hasil pengolahan data penelitian menggunakan uji Levene Statistic dari hasil belajar siswa pada kelompok eksperimen dan hasil belajar siswa pada kelompok kontrol dalam kemampuan menulis puisi menggunakan sebuah program SPSS versi 19.

\section{Tabel 3 Test of Homogeneity of Variance}

\begin{tabular}{|c|c|c|c|}
\hline \multicolumn{4}{|c|}{ Test of Homogeneity of Variances } \\
\hline & asil Belajar & & \\
\hline Levene Statistic & df1 & df2 & Sig. \\
\hline 3.940 & 1 & 40 & .054 \\
\hline
\end{tabular}

Tabel deskripsi statistik yang menjelaskan hasil pengolahan data penelitian menggunakan uji Levene Statistic dari hasil belajar siswa pada kelompok eksperimen dan hasil belajar siswa pada kelompok kontrol dalam kemampuan menulis puisi melalui program SPSS versi 19. Dapat diketahui dari tabel diatas pada deskripsi nilai kemampuan menulis puisi siswa. Nilai Signifikan yang timbul sebesar 054 yang didapat dari hasi belajar siswa melalui Test Of Homogeneity of Variances yang terdapat dalam program SPSS 19. 


\section{SIMPULAN}

Berdasarkan hasil yang diperoleh, Hasil nilai penghitungan data belajar siswa dengan menggunakan uji-t (T Test dari Anova) yang terdapat pada sebuah program SPSS versi 19. Menunjukkan bahwa yang berarti jika nilai Sig > 0,05 maka distribusi data homogen, dan jika nilai Sig $<0,05$ maka distribusi data homogen. Secara khusus temuan penelitian ini terdapat nilai Signifikan diatas nilai yang diperoleh ternyata uji-t 0,54>0,05. yang berarti nilai Sig > 0,05 maka peneliti menyimpulkan bahwa "Ada Pengaruh Model Pembelajaran Sinektik Terhadap Kemampuan Menulis Puisi Siswa Kelas VIII SMP Patra mandiri 2 Palembang.

\section{DAFTAR PUSTAKA}

Aminuddin. (2009). Pengantar Apresiasi Puisi Karya Sastra. Bandung: Sinar Baru Algensindo.

Armariena, D. N., \& Murniviyanti, L. (2017). Penulisan Cerpen Berbasis Kearifan Lokal Sumatera Selatan dengan Metode Image Streaming dalam Proses Kreatif Mahasiswa. Jurnal PEMBAHSI (Pembelajaran Bahasa dan Sastra Indonesia), 7(1), 88-115.

Armariena, D. N. (2018). Penulisan Puisi Bertema Lokal Budaya dengan Model Sugesti Mahasiswa. Parataksis: Jurnal Bahasa Sastra dan Pembelajaran Bahasa Indonesia, 1, 53-61.

Hetilaniar, \& Auliya, D. (2019). Pengaruh Strategi JUMPUT terhadap Kemampuan Membaca Puisi Siswa Kelas X SMA Negeri 10 Palembang. Wahana Didaktika Jurnal Ilmu Kependidikan, 17(2), 159-166.

Dalman. (2016). Keterampilan Menulis. Depok: Rajagrafindo Persada.

Kosasih, E. (2017). Jenis-Jenis Teks. Bandung: Yrama Widya.

Tarigan, Henry Guntur. (2008). Menulis sebagai Suatu Keterampilan Berbahasa. Bandung: Penerbit Angkasa. 